\title{
Measurement for Breath Concentration of Hydrogen and Methane in Horses
}

\author{
Naoki SASAKI, Seiji HOBO and Toyohiko YOSHIHARA \\ Equine Research Institute, Japan Racing Association, 321-4 Tokami-cho, Utsunomiya-city, Tochigi 320-0856 , Japan \\ (Received 24 November 1998/Accepted 17 May 1999)
}

ABSTRACT. This study concerns the establishment of a simple testing method for breath concentration of hydrogen and methane in horses. Twenty-eight healthy thoroughbreds and 24 Arabians were used. Breath samples were collected using one-minute closed circulatory respiration through an aluminum bag filled with 10 liters of pure oxygen, which was mounted on the subjects by means of a face mask. Breath samples obtained, were analyzed by gas chromatography. A significant correlation in both hydrogen and methane levels was observed for samples collected at separate times. These findings confirmed the usefulness of our approach for testing breath concentrations of hydrogen and methane in horses.-KEY wORDS: equine, hydrogen, methane.

J. Vet. Med. Sci. 61(9): 1059-1062, 1999

In horses, abnormality in the intestinal flora can affect digestion and absorption and lead to disorders in various digestive organs. In acute abdomen, such as ileus, bacterial overgrowth is often accompanied by aberrant intestinal motility [4]. Currently, clinical diagnosis of acute abdomen in horses is based on a combination of visual inspection, ausculation and rectal examination. However, these approaches are not sufficient to provide an objective indication of changes in bacterial growth. From a diagnostic perspective, it thus might be useful if changes to the intestinal flora could be better detected. Unfortunately, the incubation and identification of intestinal bacteria remains so complex in routine clinical approach that such changes are difficult to evaluate in vivo. In humans, hydrogen $\left(\mathrm{H}_{2}\right)$ and methane $\left(\mathrm{CH}_{4}\right)$ absorbed from the alimentary tract are transported through the blood vessels and finally discharged through the lungs by gas exchange [11,12]. A measuring method that exploits this mechanism is clinically applied to breath concentrations of $\mathrm{H}_{2}$ and $\mathrm{CH}_{4}$ in order to diagnose saccharide absorption failure $[1,5,13]$ or to measure the time required for chyme to pass through the intestinal tract $[7,15]$. In horses, where the cecum and colon are far more developed than in other mammals, gases are actively generated by the metabolism in the intestinal flora $[2,8,9]$. In addition, when administration of antibiotics causes changes in the intestinal flora resulting in diarrhea, decreased generation of $\mathrm{H}_{2}$ is reported [17]. Such findings suggest that observation of changes in gas generation in the alimentary canal would allow detection of intestinal fermentation, digestive and absorptive disorders, and abnormal intestinal motility induced by abnormal growth of the intestinal flora. In our study, we examined a simple method for measuring the breath concentrations of $\mathrm{H}_{2}$ and $\mathrm{CH}_{4}$ in equine subjects, established a reference value, and analyzed the effects of feed and age on measured breath concentration.

In our experiment, a total of 52 horses were used: 28 thoroughbreds ( 8 males, 17 females, 3 geldings; average age, $4.0 \pm 3.7$ years) and 24 Arabians (10 males, 8 females and 6 geldings; average age, $6.5 \pm 5.5$ years). All subjects were given a fixed amount of feed at 6:00 a.m. and 4:00 p.m.: hay $5 \mathrm{~kg}$, fresh pasture grass $8 \mathrm{~kg}$, oats $3 \mathrm{~kg}$, pellets 2 $\mathrm{kg}$, lucerne $1 \mathrm{~kg}$, soybean cake $0.5 \mathrm{~kg}$, linseed oil $60 \mathrm{~g}$, mineral supplements $50 \mathrm{~g}$, and salt $30 \mathrm{~g}$. Breath samples were collected using 1-minute closed circulatory respiration through an aluminum bag (AA-10, GL Sciences) filled with 10 liters of pure oxygen, which was attached to the subjects by means of a face mask (Fig. 1). After collecting breath samples, $50 \mathrm{ml}$ of the breath sample was withdrawn from the bag and $\mathrm{H}_{2}$ and $\mathrm{CH}_{4}$ levels using gas chromatography were measured (Breath $\left(\mathrm{H}_{2} / \mathrm{CH}_{4}\right)$ Analyzer TGA-2000 from TERAMECS).

To assess the repeatability of breath collection method, two samples were collected from each horse and checked for correlation. Further, average concentrations were calculated for $\mathrm{H}_{2}$ and $\mathrm{CH}_{4}$ to analyze any change in concentration with age as well as any change from one hour

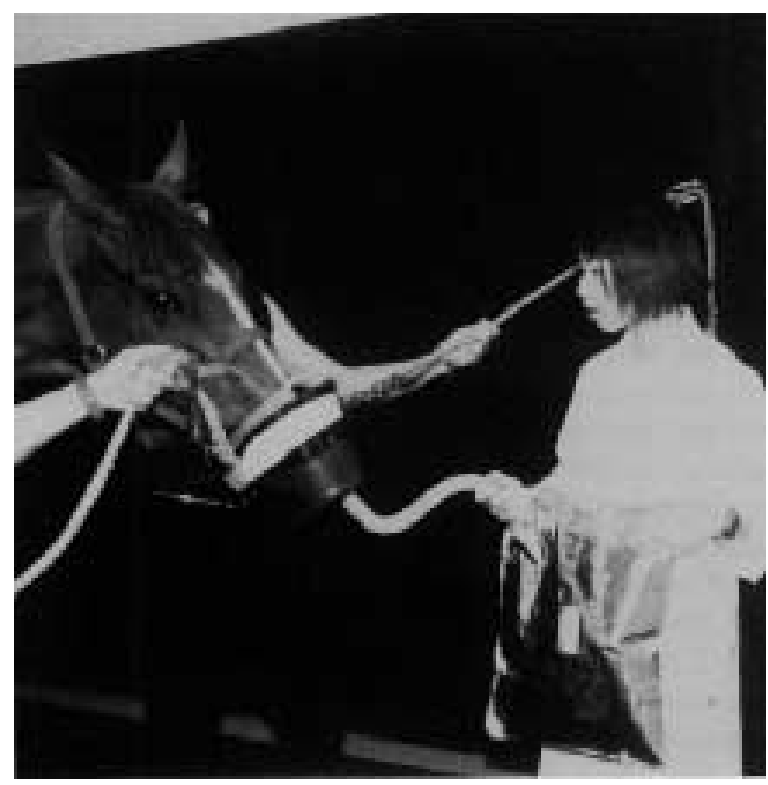

Fig. 1. Collection of $\mathrm{H}_{2}$ and $\mathrm{CH}_{4}$ from breath. Breath samples were collected using an aluminum bag filled with 10 liters of pure oxygen through 1-minute closed circulatory breathing, by means of a closed face mask mounted on the horse. 
before to one hour after feeding. These results were expressed as a mean \pm standard deviation. The Wilcoxon test was used to assess significance.

Two separate breath samples were collected from each subject. A significant correlation was noted in values from the two samples $\left(\mathrm{H}_{2}: \mathrm{r}=0.95, \mathrm{p}<0.001\right.$ and $\mathrm{CH}_{4}: \mathrm{r}=0.89$, $\mathrm{p}<0.001$ ), indicating that our method offered high reliability. The average breath concentration was $4.7 \pm 5.4 \mathrm{ppm}$ for $\mathrm{H}_{2}$ and $286.6 \pm 75.0 \mathrm{ppm}$ for $\mathrm{CH}_{4} . \mathrm{H}_{2}$ was not detected in 13 samples $(25 \%)$.

Breath concentrations of $\mathrm{H}_{2}$ decreased from 1 hour before feeding to 1 hour after, declining from $9.7 \pm 7.0 \mathrm{ppm}(\mathrm{n}=9)$ to $4.5 \pm 4.6 \mathrm{ppm}(\mathrm{n}=9)$. Nonetheless, no significant difference was observed $(\mathrm{p}=0.13)$ (Table 1). In contrast, breath concentrations of $\mathrm{CH}_{4}$ elevated significantly over the feeding interval, rising to $333.5 \pm 38.6 \mathrm{ppm}(\mathrm{n}=9)$ from $266.6 \pm 32.5 \mathrm{ppm}(\mathrm{n}=9)(\mathrm{p}<0.05)$.

In term of $\mathrm{H}_{2}$ concentration by age, the 2-year-old subjects averaged $10.9 \pm 6.4 \mathrm{ppm}(\mathrm{n}=8)$; the 3-year-olds, $2.6 \pm 2.8 \mathrm{ppm}(\mathrm{n}=12)$; the 4-year-olds, $1.3 \pm 2.5 \mathrm{ppm}(\mathrm{n}=8)$; and the 5-year-olds, $1.6 \pm 1.9 \mathrm{ppm}(\mathrm{n}=17)$ (Fig. 2). Values for both the 3-year-old $(\mathrm{p}<0.05)$ and 5-year-old subjects $(p<0.01)$ were significantly lower than that for the 2-yearolds. For $\mathrm{CH}_{4}$ concentrations, the relevant values were $269.3 \pm 33.6 \mathrm{ppm}(\mathrm{n}=8)$ for the 2-year-olds, $308.3 \pm 73.7$ ppm $(\mathrm{n}=12)$ for the 3 -year-olds, $272.8 \pm 38.9 \mathrm{ppm}(\mathrm{n}=8)$ for the 4-year-olds, and $262.8 \pm 65.7 \mathrm{ppm}(\mathrm{n}=17)$ for the 5 year-olds (Fig. 3). Values for the 5-year-old horses were significantly lower than those for the 3 -year-olds $(\mathrm{p}<0.05)$.

Michael and Levitt [12] reported in 1970 that hydrogen $\left(\mathrm{H}_{2}\right)$ and methane $\left(\mathrm{CH}_{4}\right)$ generated by intestinal bacteria were absorbed through the alimentary tract and eventually discharged from the lungs during gas exchange. Polysaccharoides, proteins and lipids in feed are taken, digested, and fermented by hydrogen-utilizing bacteria belonging to the Bacteroides and Clostridium genera, resulting in the generation of $\mathrm{H}_{2} . \mathrm{CH}_{4}$, on the other hand, is produced from $\mathrm{H}_{2}$ and $\mathrm{CO}_{2}$ by methanogenic bacteria [11] (Fig. 4). In horses, fermentation takes place in the intestine with considerable activity by the intestinal flora $[8,9]$, and $16 \%$ of the total amount of $\mathrm{H}_{2}$ generated is, then, discharged from the lungs [2]. In the case of acute abdomen, such as ileus, meteorism results from a discontinuation of intestinal motility, leading to abnormal generation of gas due to bacterial overgrowth $[4,10]$. Thus, measurement of breath concentrations of $\mathrm{H}_{2}$ and $\mathrm{CH}_{4}$ is useful in diagnosis of acute abdomen such as ileus or colic because it provides an effective indicator of bacterial growth. However, there have been few reports on $\mathrm{H}_{2}$ and $\mathrm{CH}_{4}$ concentrations in horse [3, $6,14]$ because of the difficulty of measuring breath concentrations of $\mathrm{H}_{2}$ and $\mathrm{CH}_{4}$. Previously, such measurement required a large-scale measuring instrument, and thus too complicated for clinical application [2]. However, the recent development of appropriate breathmeasuring equipment has enabled simpler and, faster measurements to be made. In the present study, we examined a simple method for measuring $\mathrm{H}_{2}$ and $\mathrm{CH}_{4}$
Table 1. Difference in breath concentration of $\mathrm{H}_{2}$ and $\mathrm{CH}_{4}(\mathrm{ppm})$ before and after feeding $(\mathrm{N}=9)$

\begin{tabular}{|c|c|c|c|}
\hline & Pre & Post & \\
\hline $\mathrm{H}_{2}$ & $9.7 \pm 7.0$ & $4.5 \pm 4.6$ & $\mathrm{P}=0.13$ \\
\hline $\mathrm{CH}_{4}$ & $266.6 \pm 32.5$ & $333.5 \pm 38.6$ & $\mathrm{P}<0.05$ \\
\hline
\end{tabular}

All data are mean \pm SD.

Pre: $1 \mathrm{hr}$ before feeding, Post: $1 \mathrm{hr}$ after feeding

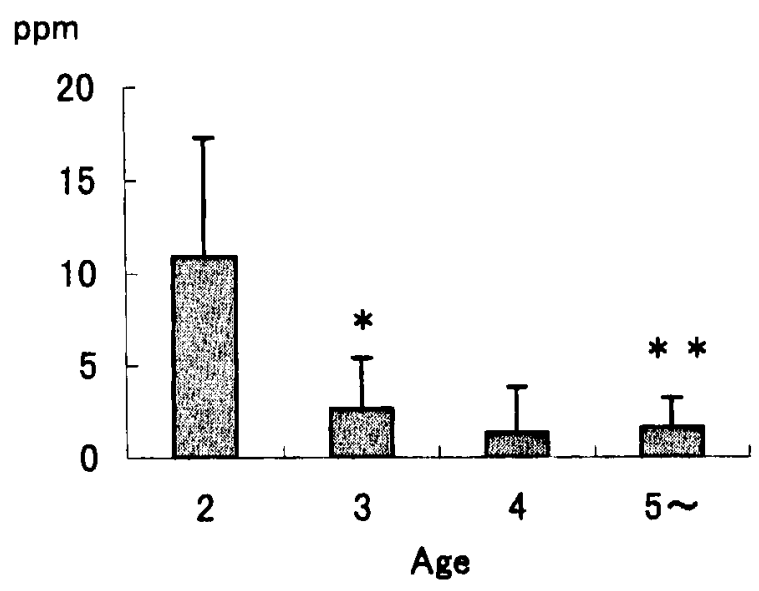

Fig. 2. Change in breath concentration of $\mathrm{H}_{2}$ by age. All data are mean $\pm \mathrm{SD}$. * : significantly low relative to 2 -year-old horses $(\mathrm{p}<0.05)$.**: significantly low relative to 2 -year-old horses $(\mathrm{p}<0.01)$

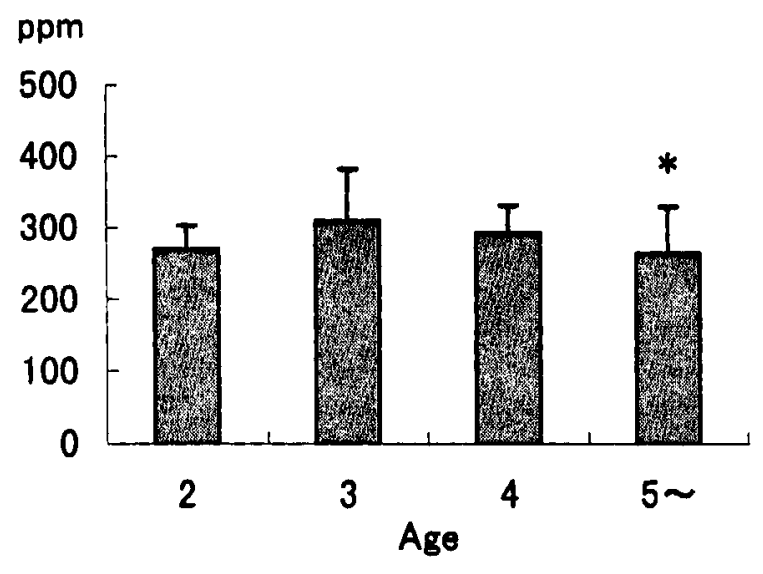

Fig. 3. Change in breath concentration of $\mathrm{CH}_{4}$ by age. All data are mean $\pm \mathrm{SD}$. *: significantly low relative to 2 -yearold horses $(\mathrm{p}<0.05)$

concentrations in equine breath, established a reference value for them, and analyzed the effects of feed and age on $\mathrm{H}_{2}$ and $\mathrm{CH}_{4}$ concentrations.

In humans, a single deep-breathing action is sufficient for breath measurement. By comparison, horses have difficulty in regulating their breathing. For this reason we employed a collection bag to allow the specimens to breath 


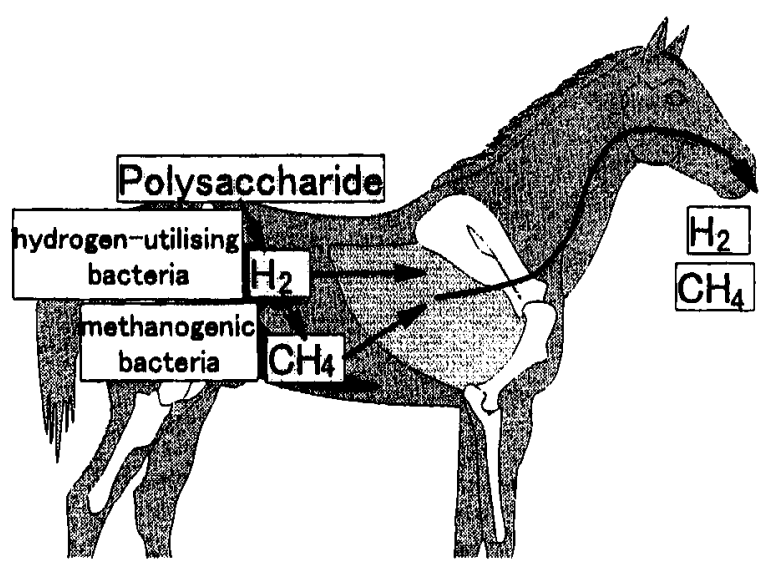

Fig. 4. Measurement mechanism for $\mathrm{H}_{2}$ and $\mathrm{CH}_{4}$ in breath. Polysaccharides, proteins and lipids taken with feed are digested and fermented by $\mathrm{H}_{2}$-utilizing bacteria belonging to the Bacteroides and Clostridium genera, and generate $\mathrm{H}_{2}$. $\mathrm{CH}_{4}$ is produced by methanogenic bacteria.

repeatedly. Specifically, breath was collected in an aluminum collection bag filled with 10 liters of pure oxygen, by permitting the subjects to breath repeatedly for $1 \mathrm{~min}$ through a closed face mask. By collecting breath over a fixed interval in this manner, it enables quantitative measurement to be obtained regardless of the subject's respiration rate, and hence offers high accuracy compared to conventional methods of collecting breath from a single breathing action [2]. There was no difficulty in collecting breath samples from most specimens. For those that resisted application of the face mask, up to three attempts were necessary before a satisfactory breath sample could be obtained. In assessing the repeatability of our breath collection, a significant correlation was observed among breath samples for both $\mathrm{H}_{2}$ and $\mathrm{CH}_{4}$ levels. Overall, we believe the method to offer both considerable repeatability and ease of use.

The average breath concentration for all subjects was 4.7 $\pm 5.4 \mathrm{ppm}$ for $\mathrm{H}_{2}$ and $286.6 \pm 75.0 \mathrm{ppm}$ for $\mathrm{CH}_{4}$. No $\mathrm{H}_{2}$ was detected in $25 \%$ of subjects. SD. of $\mathrm{H}_{2}$ were high, which are due to existence of $\mathrm{No}_{2}$. A non $\mathrm{H}_{2}$-producing type of bacteria, less capable of producing $\mathrm{H}_{2}$, has been observed in humans, and seemingly reflects a difference in intestinal bacterial flora [12]. Based on this finding, it is presumed that a non $\mathrm{H}_{2}$-producing type is also present in equines. $\mathrm{CH}_{4}$, on the other hand, was noted in all specimens, suggesting that $\mathrm{H}_{2}$ and $\mathrm{CH}_{4}$ should be added to the indicators of abnormal gas production accompanying bacterial overgrowth

Meter [16] claimed that in ponies the breath concentration of $\mathrm{H}_{2}$ decreased significantly in the first hour after consumption of fat. In our study, $\mathrm{H}_{2}$ concentrations were lower $1 \mathrm{hr}$ after feeding than $1 \mathrm{hr}$ before, though not at significant levels. In comparison, $\mathrm{CH}_{4}$ concentrations were significantly higher $1 \mathrm{hr}$ after feeding, comparing with $1 \mathrm{hr}$ before. From these results, it is concluded that the decrease in $\mathrm{H}_{2}$ concentration and the increase in $\mathrm{CH}_{4}$ concentration resulted from metabolism performed by metanogenic bacteria from $\mathrm{H}_{2}$ to $\mathrm{CH}_{4}$, which cancelled out $\mathrm{H}_{2}$ production by $\mathrm{H}_{2}$-utilizing bacteria in the alimentary canal.

Breath concentrations of $\mathrm{H}_{2}$ were significantly lower in the 3-year-old horses than those in the 2-year-olds, while concentrations of $\mathrm{CH}_{4}$ were higher in the 3-year-old horses than those in the 2-year-olds. In humans, breath concentrations of $\mathrm{CH}_{4}$ increase with age from 12 years through 50 years, while children up to 3 years of age exhale no $\mathrm{CH}_{4}$ at all [16]. From these findings, we presumed that in equines as well metanogenic bacteria would increase in number relative to $\mathrm{H}_{2}$-producing bacteria as subjects became older. Meanwhile, breath concentrations of $\mathrm{CH}_{4}$ were low in horses older than 5 years compared to those in 3-yearolds. This difference is seemed to be due to a relative reduction of metabolism from $\mathrm{H}_{2}$ to $\mathrm{CH}_{4}$ attributable to decreased production of $\mathrm{H}_{2}$. These results clearly suggest that breath concentrations of $\mathrm{H}_{2}$ and $\mathrm{CH}_{4}$ change with age, with a particularly noticeable change between 2 and 3 years of age.

In conclusion, we conclude that the method presented here provides a simple, highly repeatable means of measuring $\mathrm{H}_{2}$ and $\mathrm{CH}_{4}$ concentrations in breath. Our results also showed that $\mathrm{H}_{2}$ and $\mathrm{CH}_{4}$ concentrations vary with age and feed given. Our analysis also indicates that $\mathrm{H}_{2}$ and $\mathrm{CH}_{4}$ concentrations should be an effective indicator of intestinal fermentation, digestive and absorptive disorders, and abnormal intestinal motility associated with bacterial overgrowth in the intestines. Applicability of the present method to objective diagnoses of the alimentary canal disorders including chronic diarrhea and acute abdomen is to be investigated.

ACKNOWLEDGEMENT. The authors wish to thank Dr. Yutaka MIZUNO of Japan Racing Association, for his comments on the manuscript.

\section{REFERENCES}

1. Bahall, K. M., Scholfield, D. J., Sluijs, A. M. and Hallfrisch, J. 1998. J. Nutr. 128: 79-84.

2. Bracher, V. and Baker, S. J. 1994. Equine Vet. Educ. 6: 173176.

3. Bracher, V., Steiger, R. and Huser, S. 1995. Schweiz Arch. Tierheilkd 137: 297-305.

4. Clarke, L. L. 1990. pp. 433-450. In: Veterinary Clinics of North America: Equine Practice, Saunders, Philadelphia.

5. Eastwood, M. A. and Allgood, G. S. 1995. Eur. J. Clin. Nutr. 49: 627-639.

6. Heyer, H., Flothow, C. and Radicke, S. 1997. Arch Tierernahr 50: 63-74.

7. Jorge, J. M. N., Wexner, S. D. and Ehrenpreis, E. D. 1994. Eur. J. Surg. 160: 409-416.

8. Kern, D. L., Slyter, L. L., Weaver, J. M., Leffel, E. C. and Samuelson, G. 1973. J. Anim. Sci. 37: 463-469.

9. Kern, D. L., Slyter, L. L., Leffel, E. C., Weaver, J. M. and Oltjen, R. R. 1974. J. Anim. Sci. 38: 559-564.

10. King, J. N. and Gerring, E. L. 1991. Equine Vet. J. 23: 11-17. 
11. Mckay, L. F., Holbrook, W. P. and Eastwood, M. A. 1982. Microbiol. Immunol. Scand. Sect. 90: 257-260.

12. Michael, D. and Levitt, M. D. 1969. Production and excretion of hydrogen gas in man. New Engl. J. Med. 281: 122-127.

13. Minocha, A. and Rashid, S. 1997. Dig. Dis. Sci. 42: 672-676.

14. Murrhy, D., Howie, F. and Love, S. 1994. Equine Vet. Educ. 6: $169-172$.
15. Oufir, L. E., Flourie, B., Varannes, S. B., Barry, J. L., Cloarec, D., Bornet, F. and Galmiche, J. P. 1996. Gut. 38: 870-877.

16. Perman, J. A., Modler, S. and Olson, A. C. 1981. J. Clin Invest. 67: 643-650.

17. Solomons, N. W. 1981. pp. 91-109. In: Lactose Digestin Baltimore and London. 